\author{
A. T. Malinovskiy, \\ Candidate of Philology, \\ Associate Professor of the Department of World Literature \\ Odesa I. I. Mechnikov National University, \\ 24 / 26, Frantsuzky Blvd., Odesa, 65058, Ukraine, \\ malinowski_artur@ukr.net
}

\title{
HOSPITALITY IN UKRAINIAN LITERATURE IN THE FIRST HALF OF THE XIX CENTURY: RITUAL - ANTHROPOLOGY MODEL - CULTURAL UNIVERSAL
}

\begin{abstract}
Summary
Hospitality is considered as a kind of social-role behavior and as a type of communication in Ukrainian literature of the first half of the nineteenth century. The phenomenon of hospitality is the realization of the philosophy of dialogue, meeting I with the Other. Various manifestations of this communication in the literature are analyzed; the specific importance of ritual, anthropological model and cultural universality in the works is emphasized. Hospitality is a kind of anthropotechnics that regulates a peron's daily life, ritualizes their social relations, and distributes status roles.

Among the so-called anthropologists who present human behavior first and foremost in an ethological dimension with a stable and dynamic habit, a complex conception of the world, hospitality is perhaps the most indicative one. This category is so common that it is in some sense equal to such cultural and civilizational universals as truth, beauty, good, being. It encodes the emblem and sign sphere of life, the verbal / non-verbal behavior of a human, the discourse of communication with the Other, the special rhetoric of recognizing and accepting another into their world.
\end{abstract}

Key words: anthropology, hospitality, social-role behavior, Other, ritual.

Надійчла до редакиії 29.08.2019 p.

УДК 81'42:398.332.416(=161.2):316.346.2-055.2

DOI: https://doi.org/10.18524/2413-0613.2019.23.183136

О. В. Яковлєва,

доктор філологічних наук, професор кафедри загального та слов'янського

мовознавства філологічного факультету

Одеського національного університету імені I. І. Мечникова,

Французький бульвар 24/26, м. Одеса, 65058, Україна,

olga.yakovleva.1920@gmail.com

\section{ГЕНДЕРНИЙ СТЕРЕОТИП ФЕМІННОСТІ В КОНТЕКСТІ РИТУАЛІВ НА РІЗДВЯНІ СВЯТА В УКРАЇНСЬКІЙ ТРАДИЦЙНІЙ КУЛЬТУРІ}

Відповідно до актуальних понять у межах лінгвістичної гендерології - фемінна тендерна поведінка і маскулінна - основна увага у статті приділяється проявам стереотипу фемінності у ритуальних магічних діях дівчат і жінок на різдвяні свята в Україні. Описані та проаналізовані символічні значення окремих предметів та магічних дій, які були обов'язковими напередодні Різдва. У представленій розвідці виділяються і пояснюються „нелогічності” у виконанні деяких магічних ритуалів, які у традиційній культурі вважаються суто жіночими, зокрема, долучення чоловіка до захисних магічних дій. Відмічається аксіологічний аспект у виконанні ритуалів на різдвяні свята, акцентується увага на елементах руйнації гендерних стереотипів у наш час.

Ключові слова: гендерний стереотип, фемінність, маскулінність, ритуал, Різдво, імітативна магія. 
Дихотомія чоловічого та жіночого начал - одна 3 основоположних $\mathrm{i}$ найдавніших. Взаємодія представників обох статей споконвіку регламентується суспільством, на цей процес впливають культурні, економічні та політичні фактори, які формувалися в різні історичні періоди. В останні роки суттєво змінилися норми поведінки й оцінки людей, які відрізняються статевими ознаками. На рубежі XX-XXI ст. науковці „встановили певну закономірність, відповідно до якої жіночій статі відповідала фемінна гендерна поведінка, а чоловічій - маскулінна" [10, с. 83]. До середини минулого століття пануючим серед дослідників був консерватизм у тлумаченні гендерних ролей відповідно до фізіологічних ознак, що, в свою чергу, сприяло актуалізації поняття тендерний стереотип (цей термін був уведений у 2-й пол. ХХ ст. колективом авторів на чолі з I. Броверман), і його розуміли як загальноприйняте уявлення про розрізнювальні характеристики чоловіків і жінок [там само, с. 84]). Подальші дослідження в межах лінгвістичної гендерології, зокрема постмодерністського дискурсу [10], довели, що бурхливі зміни у суспільстві пов'язані $з$ руйнацією гендерних стереотипів i появою таких понять, як тендерна ідентичність, квір (ідентифікація маргіналізованих сексуальних нахилів) тощо.

У зв'язку з вищезазначеним, актуальним вважаємо детальний аналіз гендерного стереотипу фемінності, який, по-перше, $є$ давнішим (пор.: „Спостереження лінгвістів показують, що в протиставленні чоловік/жінка первинною була назва жінки як більш значущої для прадавнього часу людини в родовому колективі” [20, с. 104]); i, по-друге, саме цей стереотип є чітко представленим у мовних проявах традиційної культури українців.

Сучасні різноаспектні дослідження проблем лінгвістичної гендерології свідчать про те, що зацікавленість дуальною єдністю чоловічого і жіночого начала залишається на високому рівні в нашій країні. Огляду робіт у цьому аспекті присвячені праці Наталії Гоца [5]; Юлії Маслової [11]; Олени Левченко [8]. Л. Васильєва описала прояви маскулінності та фемінності на матеріалі слов'янських мов [1]. Науково-теоретична проблематика висвітлення гендерних 
стереотипів була об’єктом уваги Т. Сукаленко [18]. Актуальні проблеми гендерної ідентичності як феномена трансдисциплінарної природи проаналізовані у монографії А. Марчишиної [10].

Мета представленої розвідки - описати найважливіші традиційні обов'язки жінки-господині на різдвяні свята, проаналізувати й пояснити сакральний або символічний зміст таких ритуальних дій.

Сучасні матеріали стосовно календарних обрядів, зокрема й різдвяних свят, свідчать, що ці дні вважалися магічними; це був час повороту сонця на літо, тобто час новоліття. Таке розуміння обумовлювало й особливу ритуальну поведінку людей [4, с. 66]. Дослідники дійшли висновку, що на початку XXI ст. у багатьох українських різдвяно-новорічних обрядах вже відбулася втрата чіткого гендерного розподілу виконавців обрядовіх дій [19, с. 318]. Зараз науковці лише в загальних рисах констатують, що робили люди перед святом: „До цього часу (мається на увазі Святий вечур (вечір) - О. Я. ) треба завершити всю господарську i хатню роботи, накрити на стіл, прикрасити оселю різдвяними саморобними прикрасами - на столі покласти: свічку, ритуальний хліб „керечун”, „крайчун”, часник по краях столу під стуловкою (скатеркою), дідух, сіно, металевими лінзами обв'язати лаби (ніжки) столу” [4, с. 67]. Насправді, в ритуальних діях наших предків були чіткі гендерні розмежування. Жінки прибирали хати, які треба було двічі вибілити та вимастити, розмальовували піч або комін, образи заквітчували городнім та лісовим зіллям [7, с. 17]; все треба було перемити: вікна, двері, лави, мисники [16, с. 23]. Господиня завчасно купляла новий посуд, шила-вишивала нову білизну для всіх членів родини - все мало бути новим перед святом народження сонця, яке релігія пов'язала з народженням Ісуса Христа [16, с. 28].

Генеральне прибирання хати напередодні Різдва, з нашої точки зору, має символічне значення творення оновленого мікросвіту родини (пор.: На Святвечір все, ще є в господарстві, має бути на своєму місиі [16, с. 29]), упорядкування (пор. ряд, порядок) хаосу (безладу), захисту від негативу (тобто лиха). Різдво як свято народження нового Сонця (часи язичництва), Iсуса 
Христа (після прийняття християнства) в уявленні предків - це межа між старим і новим, минулим і майбутнім, життям і смертю; і перехід такої межі $\epsilon$ дуже небезпечним [21, с. 127-129]. У цей період активізуються всі негативні сили, захисту від яких потребує родина. Магічні ритуальні дії, спрямовані на захист сімі, виконували, як правило, жінки. Наприклад, щоб „закрити рота” своїм ворогам, господиня затикала клоччям усі дірки в лавках і ослонах [3, c. 46]. Також вона зав’язувала на мотузці стільки гудзів, скільки мала ворогів. А коли всі сідали вечеряти, жінка сідала на мотузку [3, с. 46], і це означало, що в результаті такої імітативної магії вона зав’язувала рота всім ворогам, і вони будуть мовчати протягом усього наступного року. У деяких регіонах України до захисних ритуалів долучався чоловік: він забивав дірки в лавах (щоб лихе не приховалося!), а господиня перед тим „виливала водою ці дірки” [7, с. 26], кропив хату і подвір'я свяченою водою, приносив до хати свіжої води, щоб помилися всі члени родини тощо. Таке, на перший погляд, не правомірне втручання чоловічого начала у чіткий гендерний розподіл магічних ритуальних дій (зокрема, суто жіночим був обов'язок забезпечувати сім’ю водою; тільки жінки в обрядах набирали так звану досвітню воду) ми пояснюємо тим, що на різдвяні свята чоловік символічно виконував роль жерця, ототожнювався 3 божеством, у присутність якого при виконанні всіх справ свято вірили.

I. Нечуй-Левицький звернув увагу на те, що у колядках згадується давній міфічний образ якогось світлого бога на ім’я Пан Господар. „Пан Господар, пише дослідник, - то давній найстарший бог світла або неба, схожий на індійського Варуну, котрий збудував світ і вивів на небо сонце й зорі...” [12, с. 15-16]. У щедрівках з Лемківщини закарбована ідея про те, що новоліття (новий рік) має зустрічати пан господар як сам Господь Бог: Bcmaнь, газдо, горi - Новий Рік у дворі; пускай старий, приймай Новий Рік до хати! [6, с. 2]. Суто жіночою справою було приготування на Святу Вечерю дванадцяти ритуальних страв, куті та узвару. Тут мали місце регіональні відмінності: Кутю у нас (на Закарпатті - О. Я.) не варили, а обов'язковою була фасоля з грибами, капустою, варили пироги (вареники) із капустою, картоплю, ивабські трині, вар 
(компот), смажена риба, гриби, хліб [4, с. 68]. Але першою магічною дією господині було добування нового вогню, коли вона, ставши обличчям до схід сонця, викресала „новий огонь” [3, с. 45] і розпалювала піч. 3 трипільських часів сакральним вважалося місце, де зберігався вогонь у печері, пізніше - у хаті. „Піч - наче мати рідна”, - казали в давнину. 3 тих часів хатнім вогнем опікувалась господиня [21, с. 190-191]. Традиційна роль жінки при випіканні обрядового хліба закарбована у стародавній колядці: Ци дома, дома господинечка? Єсть вона дома, в новій світлониі. Що ж вона робить? - Колачі плете [2, с. 230].

В різних регіонах України на Різдво випікали різний обрядовий хліб. На Поліссі це були „круглі форми - паляниці, менші хлібинки - палінки, кулідки, коржики, пампушки, млинці тощо. На Наддніпрянщині пекли паляниці, пироги, калачі, книші... Для закликання душ предків з вирію..., випікали пташки” [15, c. 281]. На Закарпатті цікавим передріздвяним ритуалом було випікання особливого обрядового хліба, який називали крайчун (корочун, карачун, кречун, красун, керечун тощь). В. Войтович зауважив, що питання етимології даного слова залишається відкритим [2, с. 247]. Російські дослідники пов'язують цей відомий у карпатсько-балканському ареалі календарний термін зі спільнослов'янським дієсловом korciti, що перекладається рос. ,идти, багать”. Різдвяний хліб корочун був символом багатства сім'ї, хазяйка випікала його 3 особливими пересторогами, одягнувши вивернутий кожух і рукавиці, щоб забезпечити добробут у родині; з цим хлібом дівчата гадали, а крихти треба було спалити або закопати в землю [17, с. 468-469]. Українські дослідники вважають, що такий „хлібець”, як карачун, символізував зимове сонцестояння, він супроводжував усі святки, а вживали його „після Василів (14 січня - О. Я.) і тримали до весни, щоб вийти з ним на перший засів яровини” [16, с. 32-33]. Випікала карачун господиня або ввечері, або у ніч перед Різдвом, або „мама пекла крайчун під час вечері... Спечений крайчун мав стояти на столі до Василія разом із вівсяним снопом” [4, с. 68]. Ритуал випікання карачуна у гуцулів передбачав, щоб жінка „одягалася в гуню і натягала рукавицю, бо гола 
рука - це бідність, а крачун - символ достатку" [16, с. 32]. Гуня (гуцульська гугля) - це елемент обрядового весільного вбрання, мала форму мішка, не зашитого з одного боку. Ї̈̈ накидали на плечі і чоловіки, і жінки. За кроєм гуня нагадувала поховальний саван, а також ця накидка перегукується 3 перев'язуванням немовляти повивачем. Такі ритуальні форми одягу об'єднує ідея кокоморфності як символічна характеристика тіла лімінальних персонажів [9, с. 191-194]. Лімінальні особи - це головні особи в сімейних обрядах (народження дитини, весільному та поховальному), які ще називають обрядами переходу [21, с. 124-134]. Різдво як один 3 найважливіших календарних обрядів теж належить до обрядів переходу, а жінка, яка випікала карачун (зазвичай цей хліб мав круглу форму, і як багатозначний символ асоціювався із сонцем, народження якого святкували), була причетна до ритуалу „народження”, отже, iї гуня символізувала таку лімінальну особу. Всі без винятку обряди переходу були небезпечними, вони мають спільну організуючу ідею межі між цим світом і потойбіччям (обряд народин і поховальний), а також межі між „своїм” (світом) та „чужим” у весільному обряді. Щоб захистити від злих сил себе і всю родину, худобу та майно, господар, наділений божественною силою, тільки на Різдво виконував низку захисних ритуалів. Наприклад, на Закарпатті захисні магічні дії виконували господар із сином [16, с. $33-34 ; 7$, с. 21$]$.

В сімейних обрядах функцію захисниці-берегині брала на себе жінка. Та й під час різдвяних свят вона теж долучалася до таких ритуалів. В. Скуратівський зауважив: коли не було сина, обхід робив господар з дружиною, яка одягала чоловічу шапку [16, с. 33]. О. Воропай додає: обходили двір зі „святочним” хлібом, медом та маком господар і господиня (виділено нами - О. Я). „Біля обори, де стоять корови, господиня густо посипає насінням дикого маку, - щоб відьми, його визбируючи, не могли приступити до худоби. ... Йдучи в обхід, жінка вбирає собі на голову чоловічу шапку, - щоб цілий рік ходити простоволосою” [3, с. 47]. Перевдягання взагалі та вдягання жінкою чоловічої шапки зокрема, робилося в давнину з ціллю „збити з пантелику”, „заплутати 
злих духів", щоб вони не встигли нашкодити. Тож жінка, яка вбиралась у чоловічу шапку, символічно допомагала чоловікові виконувати функцію захисника сім'ї та всього хазяйства, підсилюючи його божественну енергію. Вдягання чоловічої шапки з ціллю ходити протягом року простоволосою має символічне значення, що пов'язане з волоссям взагалі.

По-перше, покривання голови дівчини (жінки), коли не ховається коса, мало символічне значення здоров'я, краси, багатства та плідності. [14, с. 152]. Чоловіча шапка в цьому ритуалі, скоріше за все, не закривала все волосся жінки, як це було у випадку з хустиною (очіпком): заміжні жінки не ходили 3 непокритою головою. По-друге, покривання волосся, - на думку О. Потебні, позбавляло жінку (дівчину) таємничої сили, здатності ворожити, чаклувати. Останні обрядові дії виконувались жінками з непокритою головою [14, с. 151152]. Отже, бажання ходити протягом року простоволосою ми розуміємо як право жінки, якого вона позбавлялась на Різдво, повернути собі магічну силу, бути головним суб’єктом і об’єктом у майбутніх сімейних і календарних обрядах, здатність виконувати всі інші ритуали.

На Різдво в межах хати (це був жіночий простір мікросвіту родини) господиня виконувала такі ритуали: під скатертину, якою накривали стіл перед Святою вечерею, по всіх чотирьох кутах вона укладала часник, промовляючи магічні слова: Злая сило, темна сило, іди на болота, очерети, яри-скелі, у глибокі води-прірви, куди курячий голос не доходить, куди світ-сонце не світить... [7, с. 25]. Мати-хазяйка свяченою водою освячувала вечерю перед тим, як родина сідала за стіл. Стійким є вірування, що на Різдво до хати першим має зайти представник чоловічої статі. Тоді в родині всі будуть щасливими, здоровими і багатими. „А якщо першою зайде жінка, то в домі оселяться хвороби й негаразди. Порядні господині боялися на Різдво йти у гості без запрошення" [4, с. 66]. Як і в інших народів, в українській міфології смерть i хвороби уособлюються в образі жінки, хоча $є$ дані про невизначеність обличчя смерті, iї зооморфність у вигляді ведмедя, зайця, кішки, жаби тощо [21, с. 122]. 3 описаним вище пов'язують і ритуали колядування. Першими по більшій 
частині України колядували діти, зазвичай хлопчики 7-8 років; вони заходили до хати, бо хлопчик символізував прибуток і успіх. Дівчата, як правило, не ходили або не заходили до хати. С дані, що в деяких місцевостях України, крім хлопчачих, ходили й дівочі ватаги [16, с. 40]. Сьомого січня колядувала церковна громада, збираючи гроші для церкви; а ввечері колядували вже всі: i хлопці, і дівчата. Результати польових досліджень календарної обрядовості в Одеській області в середині минулого століття свідчать про нівелювання гендерних особливостей у ритуалах на різдвяні свята. Наприклад, бажано, щоб на Різдво першим зайшов чоловік або хлопчик - тоді родина буде здорова. Якщо ж першою прийде жінка, то нічого не буде. Інший варіант: „якщо першою зайде жінка, у господарстві з’явиться теличка, а коли чоловік, то буде бичок" [13, с. 269].

Отже, в минулому столітті в різних регіонах України ритуали на різдвяні свята втратили не тільки гендерні особливості (пор.: „...замість парубочих ma чоловічих гуртів колядників..., виконавиями до того суто чоловічого фольклору стали дівчата та жінки, які іноді виражають протест, коли старші люди не пускають їх колядувати" [19, с. 316]), а й перестали бути магічними діями, направленими на примноження добробуту в сім’ї та на захист родини. Проведений аналіз етнографічного матеріалу дозволяє зробити висновки стосовно стереотипу фемінності, закарбованого в ритуалах на різдвяні свята у традиційній культурі українців. Перш за все, жінка опікувалась мікросвітом родини, вона була берегинею порядку в сім’ї (пор.: Нащ̧о кращчий скарб, коли в сім'ї лад; В хаті жінка три кути держить, муж-четвертий). Перед Різдвом, яке у віруваннях асоціювалося $з$ оновленням світу, дівчата 3 соломи та житніх стебел робили павуків (пор.: на Поліссі такого павука називали „солом’яник”; ними прикрашали покуття, i то була складна система - модель сотворіння Світу $[15$, с. 279]), з тіста або глини виготовляли їжаків, щоб прикрасити оселю; жінки займались символічним оновленням мікросвіту своєї родини: вони мили, білили, чепурили піч, шили новий одяг тощо. По-друге, суто жіночою справою було виконання захисних ритуалів у календарних та сімейних обрядах. Різдво в 
цьому плані не було винятком, хоча в цих ритуалах жінка грала другорядну роль помічниці. По-третє, жінка в традиційній культурі - хранителька домашнього вогнища (пор.: Жіноча дорога - від печі до порога). На Різдво вона „добувала новий вогонь”, готувала ритуальні страви, пекла ритуальний хліб, накривала на стіл разом із чоловіком. Колядування на різдвяні свята віддзеркалює прадавній архетип чоловічого начала як позитивного, жіночого - як негативного. Хоча такі гендерні стереотипи в середині минулого століття в різних регіонах України вже були майже зруйновані.

Перспективним у майбутніх розвідках буде аналіз проявів маскулінності та фемінності в українській традиційній культурі в обрядовому дискурсі в широкому значенні, куди увійдуть і ритуали календарних та сімейних обрядів, i обрядові пісні, що супроводжують майже всі ритуальні дії.

\section{Список використаної літератури та джерел}

1. Васильєва Л. Маскулінність і фемінність у мові (на матеріалі слов'янських та неслов'янських мов) // Слов'янський збірник: Зб. наук. праць. Чернівці: Букрек, 2017. Вип. 21. С. 141156.

2. Войтович В. М. Українська міфологія. Вид. 2-е, стер. К. : Либідь, 2005. 664 с.

3. Воропай Олекса. Звичаї нашого народу. К. : Оберіг, 1993. 592 с.

4. Гайова Є. Філософія буття в лемківських зимових обрядах та звичаях (Різдво, Василія, „бабин святий вечір”, Івана Хрестителя, Стрітення Господнє) на експедиційних матеріалах, зібраних у Великоберезянському районі Закарпатської області // Календарна обрядовість у життєдіяльності етносу. Збірка наукових праць. Мат. міжнар. наук. конф. „Одеські етнографічні читання”. Одеса, 2011. C. $65-75$.

5. Гоца Н. Вивчення мови крізь призму гендерних теорій // Мовознавство, 2013. №5. С. 5558.

6. Жіноча воля. Двотижневик для сільського жіноцтва. Коломия, 1-7 січня 1934 р. С. 2.

7. Килимник С. Український рік у народних звичаях в історичному освітленні. Т.1: Зимовий цикл. Торонто, 1964. 154 с.

8. Левченко О. Лінгвістичні дослідження гендеру в Україні // Людина. Комn'ютер. Комунікація: збірник наукових праць.Львів : Вид-во Львівської політехніки, 2017. С. 74-83.

9. Маєрчик М. Ритуал і тіло. Структурно-семантичний аналіз українських обрядів родинного циклу : монографія. К. : Критика, 2011. 326 с.

10.Марчишина А. А. Гендерна ідентичність в англомовному постмодерністському дискурсі: соціокультурний та лінгвопоетичний аспекти (на мат. наукових, публіцистичних та художніх текстів): монографія. Кам’янець-Подільський: ПП Буйницький О. А., 2018. 452 с. 
11.Маслова Ю. Особливості розвитку гендерних лінгвістичних досліджень в Україні // Наукові записки наиіонального університету „Острозька академія”. Сер. „філологічна”. 2015. Вип. 5-7. С. 100-105.

12.Нечуй-Левицький І. Світогляд українського народу. Ескіз української міфології. 2-е вид. К. : Обереги, 2003. 144 с. середини

13. Петрова Н. Календарна обрядовість українців Миколаївського району Одеської області

XX ст.: нові польові матеріали // Календарна обрядовість у життєдіяльності етносу. Збірка наукових праць. Мат. міжнар. наук. конф. „Одеські етнографічні читання”. Одеса, 2011.

14.Потебня А. Символ и миф в народной культуре / Сост., подг. текстов, статья, коммент. А. Л. Топоркова. М.: Лабиринт, 2007. 480 с.

15.Свирида Р. Українська Коляда на теренах Полісся й Наддніпрянщини // Календарна обрядовість у життєдіяльності етносу. Збірка наукових праць. Мат. міжнар. наук. конф. „Одеські етнографічні читання". Одеса, 2011. С. 278-287.

16.Скуратівський В. Святвечір. (у 2 к.). К.: Вироб.-комерц. фірма „Перлина”, 1994.

17.Славянские древности: этнолингвистический словарь : [в 5 т.]. Т. 2. / под ред. Н. И. Толстого. М. : Межд. отношения, 1999. 697 с.

18.Сукаленко Т. М. Метафоричне вираження концепту ЖІНКА в українській мові: Монографія. К., Видавничий дім Дмитра Бураго, 2010. 240 с.

19.Сушко В. Різдвяно-новорічна обрядовість українців Слобожанщини у ХХ ст. // Календарна обрядовість у жстттеділльності етносу. Збірка наукових праць. Мат. міжнар. наук. конф. „Одеські етнографічні читання". Одеса, 2011. С. 313-321.

20.Таранець В. Г. Діахронія мови : збірник статей. Одеса : Друкарський дім, 2008. 232 с.

21.Яковлєва О. В. Обрядовий дискурс у системі національної лінгвоментальності : монографія. Одеса: Одеський національний університет імені I. I. Мечникова, 2014. 396 с.

\section{References}

1. Vasylieva L. Maskulinnist i feminnist u movi (na materiali slovianskykh ta neslovianskykh mov) // Slovianskyi zbirnyk: Zb. nauk. prats. Chernivtsi: Bukrek, 2017. Vyp. 21. P. 141-156.

2. Voitovych V. M. Ukrainska mifolohiia. Vyd. 2-e, ster. K. : Lybid, 2005. 664 p.

3. Voropai Oleksa. Zvychai nashoho narodu. K. : Oberih, 1993. 592 p.

4. Haiova Ye. Filosofiia buttia v lemkivskykh zymovykh obriadakh ta zvychaiakh (Rizdvo, Vasyliia, „babyn sviatyi vechir”, Ivana Khrestytelia, Stritennia Hospodnie) na ekspedytsiinykh materialakh, zibranykh u Velykoberezianskomu raioni Zakarpatskoi oblasti // Kalendarna obriadovist u zhyttiediialnosti etnosu. Zb.nauk.prats. Mat. mizhnar. nauk. konf. „Odeski etnohrafichni chytannia”. Odesa, 2011. P. 65-75.

5. Hotsa N. Vyvchennia movy kriz pryzmu hendernykh teorii // Movoznavstvo. 2013.№ 5. P. 55-58.

6. Zhinocha volia. Dvotyzhnevyk dlia silskoho zhinotstva. Kolomyia, 1-7 sichnia 1934 r. P. 2.

7.Kylymnyk S. Ukrainskyi rik u narodnykh zvychaiakh v istorychnomu osvitlenni. T.1: Zymovyi tsykl. Toronto, 1964. $154 \mathrm{p}$.

8. Levchenko O. Linhvistychni doslidzhennia henderu v Ukraini // Liudyna. Kompiuter. Komunikatsiia : zbirnyk naukovykh prats.Lviv : Vyd-vo Lvivskoi politekhniky, 2017. P. 74-83. 
9. Maierchyk M. Rytual i tilo. Strukturno-semantychnyi analiz ukrainskykh obriadiv rodynnoho tsyklu : monohrafiia. K. : Krytyka, 2011.326 p.

10. Marchyshyna A. A. Genderna identychnist v anhlomovnomu postmodernistskomu dyskursi: sotsiokulturnyi ta linhvopoetychnyi aspekty (na mat. naukovykh, publitsystychnykh ta khudozhnikh tekstiv): monohrafiia. Kamianets-Podilskyi: PP Buinytskyi O. A., 2018. 452 p.

11. Maslova Yu. Osoblyvosti rozvytku hendernykh linhvistychnykh doslidzhen v Ukraini // Naukovi zapysky natsionalnoho universytetu «Ostrozka akademiia». Seriia „filolohichna”. 2015. Vyp. 5-7. P. 100105.

12. Nechui-Levytskyi I. Svitohliad ukrainskoho narodu. Eskiz ukrainskoi mifolohii. 2-e vyd. K. : Oberehy, 2003. 144 p.

13. Petrova N. Kalendarna obriadovist ukraintsiv Mykolaivskoho raionu Odeskoi oblasti seredyny KhKh st.: novi polovi materialy // Kalendarna obriadovist u zhyttiediialnosti etnosu. Zbirka naukovykh prats. Mat. mizhnar. nauk. konf. „Odeski etnohrafichni chytannia”. Odesa, 2011.

14. Potebnia A. Symvol y myf v narodnoi kulture / Sost., podh. tekstov, statia,komment. A. L. Toporkova. M.: Labyrynt, 2007. 480 p.

15. Svyryda R. Ukrainska Koliada na terenakh Polissia y Naddniprianshchyny // Kalendarna obriadovist u zhyttiediialnosti etnosu. Zbirka naukovykh prats. Mat. mizhnar. nauk. konf. „Odeski etnohrafichni chytannia". Odesa, 2011. P. 278-287.

16. Skurativskyi V. Sviatvechir. (u 2 k.). K.: Vyrob.-komerts. firma „Perlyna”, 1994.

17. Slavianskye drevnosty: etnolynhvystycheskyi slovar : [v 5 t.]. T. 2. / pod red. N. Y. Tolstoho. M. : Mezhd. otnoshenyia, 1999. 697 p.

18. Sukalenko T. M. Metaforychne vyrazhennia kontseptu ZhINKA v ukrainskii movi: Monohrafia. K., Vydavnychyi dim Dmytra Buraho, 2010. 240 p.

19. Sushko V. Rizdviano-novorichna obriadovist ukraintsiv Slobozhanshchyny u KhKh st. // Kalendarna obriadovist $\mathrm{u}$ zhyttiediialnosti etnosu. Zbirka naukovykh prats. Mat. mizhnar. nauk. konf. „Odeski etnohrafichni chytannia”. Odesa, 2011. P. 313-321.

20. Taranets V. H. Diakhroniia movy : zbirnyk statei. Odesa : Drukarskyi dim, 2008. 232 p.

21. Yakovleva O. V. Obriadovyi dyskurs u systemi natsionalnoi linhvomentalnosti : monohrafia. Odesa: Odeskyi natsionalnyi universytet imeni I. I. Mechnykova, 2014. 396 p.

\section{O. V. Yakovleva,}

Doctor of Philology, Full Professor

of General and Slavic Linguistics Department,

Odesa I. I. Mechnikov National University,

24 / 26, Frantsuzky Blvd., Odesa, 65058, Ukraine,

olga.yakovleva.1920@gmail.com

\section{GENDER STEREOTYPE OF FEMININITY IN THE CONTEXT OF RITUALS ON CHRISTMAS IN UKRAINIAN TRADITIONAL CULTURE}

\section{Summary}

The dichotomy of male and female origins is one of the most fundamental and ancient. The interaction of the representatives of both sexes is initially regulated by society. Hence cultural, economic and political factors, which are formed in different historical periods, influence this process. Modern, impetuous changes 
in society are associated with the destruction of gender stereotypes and the emergence of concepts such as gender identity, queer (identification of marginalized sexual inclinations), etc.

The purpose of the article is to describe the most important traditional duties of the Ukrainian womanmistress on Christmas holidays, to analyze and explain the sacred or symbolic content of such ritual actions. At the beginning of the XXI century in many Ukrainian Christmas and New Year rituals there has already been a loss of a clear gender distribution of ritual duties. However, in the ritual actions of our ancestors, there were clear gender divisions: the woman took care of the microcosm of the family, was engaged in its symbolic renewal; she guarded the customs of the family. It was purely a woman's job to perform protective rituals: the hostess put garlic under a tablecloth on all four corners of the table, sanctified dinner with holy water before the family sat down at the table, and so on. In the Ukrainian traditional culture, a woman is the keeper of the hearth. At Christmas she "extracted a new fire", prepared ritual dishes, baked holy ritual bread, and laid the table. Caroling on Christmas holidays reflects the ancient archetype of masculine origin as a positive, female - as a negative. However such gender stereotypes in the middle of the last century in various regions of Ukraine have already been almost ruined. The analysis of masculinity and femininity in the Ukrainian traditional culture in a ritual discourse in a broad sense, which include the rituals of calendar and family rites, and ceremonial songs that accompany almost all ritual actions will be prospective for future articles.

Key words: gender stereotype, femininity, masculinity, ritual, Christmas, imitative magic.

Надійшла до редакиії 31.07.2019 p. 